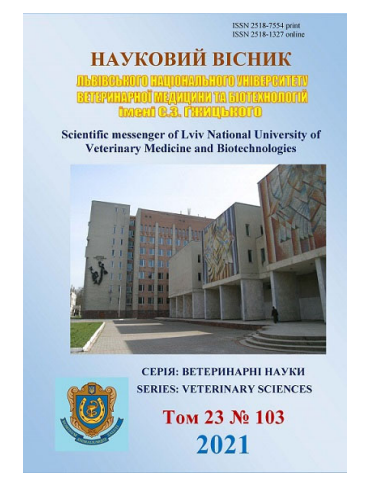

Науковий вісник Дьвівського національного університету ветеринарної медицини та біотехнологій імені С.3. Гжицького. Серія: Ветеринарні науки

Scientific Messenger of Lviv National University of Veterinary Medicine and Biotechnologies. Series: Veterinary sciences doi: $10.32718 /$ nvlvet10308 https://nvlvet.com.ua/index.php/journal

UDC 636.09:616.99-093/-098(477)

\title{
Monitoring of the epizootic situation sheep strongyloidiasis on Ukrainian territory
}

S. Sorokova

Poltava State Agrarian University, Poltava, Ukraine

Article info

Received 01.07.2021

Received in revised form 04.08 .2021

Accepted 05.08.2021

Poltava State Agrarian University, Skovorody Str., 1/3,

Poltava, 36003, Ukraine. Tel.: +38-066-089-25-61 E-mail: svetagirl911@gmail.com
Sorokova, S. (2021). Monitoring of the epizootic situation sheep strongyloidiasis on Ukrainian territory. Scientific Messenger of Lviv National University of Veterinary Medicine and Biotechnologies. Series: Veterinary sciences, 23(103), 51-55. doi: 10.32718/nvlvet10308

One of the reasons that reduce the efficiency of sheep breeding development and lead to significant economic losses of the industry in Ukraine and the world is helminthic diseases, particularly strongyloidiasis caused by parasitic nematodes. Strongyloides parasitize in the small intestine of animals and lead to slow growth and development of young sheep, diarrhea, anemia, ataxia. At the high intensity of invasion animals can die. The study aimed to analyze monitoring studies on the prevalence of strongyloidiasis in sheep in Ukraine based on statistical data of the reporting documentation of the State Research Institute for Laboratory Diagnostics and Veterinary Sanitary Examination during 2016-2020. Studies have shown that helminthiasis of sheep is a common invasion in farms of various forms of ownership in Ukraine, where the extent of the invasion ranged from 1.44 to $3.27 \%$. The share of helminthiasis of the digestive tract of sheep from the total number of detected helminthiasis reaches $84.21 \%$. The most common of the helminthiases of the gastrointestinal tract were nematodes; their share was $63.07 \%$. Trematodes and cestodes were diagnosed less frequently; their share among helminthiases of the digestive tract was 35.05 and $1.88 \%$, respectively. It was found that among the nematodes of the digestive tract parasitizing in sheep in Ukraine, the largest share was strongylidosis, in particular bunostomosis, nematodyrosis, hemonchosis (65.20\%), and strongyloidiasis $(33.92 \%)$. A smaller proportion were esophagostomosis $(0.74 \%)$ and trichurosis $(0.14 \%)$. Indicators of prevalence were: for strongylidosis (bunostomosis, nematodyrosis, hemonchosis) $10.98 \%$, for strogiloidiasis $-4.48 \%$, for esophagostomosis $-0.42 \%$, for trichurosis $-0.21 \%$. In terms of years, the rates of damage to sheep by the causative agent of strongyloidiasis fluctuated significantly with the increasing prevalence of strongyloidiasis invasion during 2019-2020. Indicators of infestation of sheep with the causative agent of strongyloidiasis during the study period in Ukraine were at the level of $1.91 \%$ (2018) to $16.14 \%$ (2019). The data we obtained testify to the urgency of the problem of nematodes, particularly strongyloidiasis of sheep in Ukrainian farms, and lead to more thorough research on epizootological, biological features of the causative agent strongyloidiasis and the introduction of effective treatment and prevention measures.

Key words: helminthiasis, strongyloidiasis, sheep, spread, epizootic situation, prevalence of invasion.

\section{Моніторингові дослідження епізоотичної ситуації щодо стронгілоїдозу овець на території України}

\author{
С. С. Сорокова
}

Полтавський державний аграрний університет, м. Полтава, Украӥна

Однією з причин, яка знижує ефективність розвитку вівчарства та призводить до значних економічних збитків галузі в Україні та світі є гельмінтозні захворювання, зокрема стронгілоїдоз, викликаний паразитичними нематодами. Стронгілоїдеси паразитують в тонкому кишечнику тварин і призводять до сповільнення росту й розвитку молодняку овець, появи діареї, анемії, атаксї, а за високої інтенсивності інвазії- тварини можуть гинути. Метою роботи було провести аналіз моніторингових досліджень щуодо поширення нематодозів шлунково-кишкового тракту, зокрема стронгілоїдозу овець в Украӥні за результатами статистичних даних звітної документації Державного науково-дослідного інституту з лабораторної діагностики та ветеринарно- 
санітарної експертизи впродовж 2016-2020 рр. Проведеними дослідженнями встановлено, щзо гельмінтози овець є поширеними інвазіями в господарствах різних форм власності на території України, де показники екстенсивності інвазії коливалися від 1,44 до 3,27\%. Частка гельмінтозів травного каналу овець із загальної кількості виявлених гельмінтозів сягає 84,21 \%. Найбільш поширеними з гельмінтозів шлунково-кишкового тракту виявилися нематодози, їх частка становила 63,07 \%. Рідше діагностували трематодози ти цестодози, їх частка серед гельмінтозів травного каналу відповідно склала 35,05 та 1,88 \%. Встановлено, ио серед нематодозів травного каналу, щьо паразитують у овець на території України найбільшу частку становили стронгілідози, зокрема буностомоз, нематодироз, гемонхоз (65,20\%) та стронгілоїдоз (33,92 \%). Меншу частку становили езофагостомоз (0,74\%) та трихуроз (0,14\%). Показники екстенсивності інвазї становили: за стронгілідозів (буностомоз, нематодироз, гемонхоз) - 10,98 \%, за строгілоїдозу - 4,48 \%, за езофагостомозу - 0,42\%, за трихурозу - 0,21\%. У розрізі років показники ураження овець збудником стронгілоїдозу мали значні коливання із зростанням екстенсивності строгілоїдозної інвазії впродовж 2019-2020 років. Показники інвазованості овець збудником стронгілоїдозу за досліджений період на території України знаходилися на рівні від 1,91 \% (2018 р.) до 16,14\% (2019 р.). Отримані нами дані свідчать про актуальність проблеми щодо нематодозів, зокрема стронгілоїдозу овець у господарствах України $і$ зумовлюють проведення більш трунтовних досліджень відносно епізоотологічних, біологічних особливостей збудника стронгілоїдозу та впровадження ефективних лікувально-профілактичних заходів.

Ключові слова: гельмінтози, стронгілоїдоз, вівці, поширення, епізоотична ситуачія, екстенсивність інвазї.

\section{ВстуII}

Останнім часом однією з актуальних проблем вівчарства, особливо в умовах невеликих приватних і фермерських господарств, є нематодози, які завдають галузі значних економічних збитків (Vdovychenko, 2013). Одним з поширених нематодозів овець є стронгілоїдоз, який може перебігати як моноінвазія, так і у вигляді асоціативних інвазій. Спалахи стронгілоїдозу 3 масовою загибеллю тварин описані в Японії (Taira et al., 1991; 1992; Tsuji et al., 1992; Ura et al., 1992; 1993; Nakanishi et al., 1993; Nakamura et al., 1994; Kobayashi et et al., 2009). За даними науковців, в Саратовській області Російської Федерації відсоток інвазованості овець стронгілоїдесами в господарствах коливався від 15,2 до $54,9 \%$ і склав в середньому по області $31,4 \%$ (Chemodankina, 2007). На території Білорусі в приватних господарствах країни 22,37-37,24 \% овець були заражені збудником стронгілоїдозу, де відсоток екстенсивності інвазії коливався в межах від 19,89 до 26,1 \% (Samsonovich, 2012). В Ефіопії поширеність шлунково-кишкових нематодозів овець, зокрема стронгілоїдозу склала 75,8 \% (Asmare et al., 2016). Британські вчені в своїх працях звертають увагу на значну поширеність стронгілоїдозу на території Англії, Шотландії, Уельсу та Північної Ірландії (McMahon et al., 2012). Дослідники з Малі, також, звертають увагу на високу розповсюдженість стронгілоїдозу в молодняку дрібної рогатої худоби порівняно 3 іншими гельмінтозами (Wymann, 2007). В умовах господарств Індії, в районі Джабалпур штату Мадх'яПрадеш, 82,75 \% досліджених проб фекалій дрібної рогатої худоби виявилися позитивними на гельмінтози, з яких 0,79\% становив Strongyloides spp. (Dixit et al., 2017). А в долині Кашмір стронгілоїдоз був одним 3 найбільш поширених інвазій овець, їх інвазованість становила 15,5 \% (Bhat, 2012). За даними досліджень вчених, в Сгипті екстенсивність інвазії овець Strongyloides papillosus становила близько 4,02\% (Sultan et al., 2016). Проте, незважаючи на велику кількість даних щодо поширеності даної інвазії на території інших держав, на даний момент відсутні єдині узагальнені дані щодо поширеності стронгілоїдозу овець на території України. Тому метою роботи було провести аналіз моніторингових досліджень щодо поширення стронгілоїдозу овець в Україні.

\section{Матеріал і методи досліджень}

Моніторингові дослідження щодо поширення стронгілоїдозу та інших гельмінтозів овець на території України проводили за результатами аналізу статистичних даних звітної документації Державного науково-дослідного інституту з лабораторної діагностики та ветеринарно-санітарної експертизи (м. Київ) впродовж 2016-2020 pр. Враховували показники кількості досліджених та інвазованих тварин збудниками гельмінтозів шлунково-кишкового тракту, органів дихання, а також стронгілоїдозу. Вираховували показники екстенсивності інвазії (ЕI, \%).

Усі маніпуляції з тваринами проводили відповідно до Європейської конвенції про захист хребетних тварин, які використовуються для експериментальних i наукових цілей (Official Journal of the European Union L276/33, 2010).

\section{Результати та їх обговорення}

За результатами проведених моніторингових досліджень встановлено, що гельмінтозні захворювання овець $є$ значно поширеними на території України, де середня екстенсивність інвазії становила 2,43 \%. Водночас, продовж досліджених років спостерігали незначні коливання показників ураженості овець збудниками гельмінтозів, які становили: у 2016 р. - 2,40 \% (з 118138 досліджених овець 2841 голів виявилися інвазованими), у 2017 р. - 3,27 \% (з 180660 досліджених - 5904 інвазовано), у 2018 р. - 1,44 \% (з 155974 досліджених - 2244 інвазовано), у 2019 р. - 2,64 \% (3 72237 досліджених - 1906 інвазовано), у 2020 р. 2,26\% (з 62291 досліджених - 108 інвазовано) (рис. 1).

Визначено, що найбільш поширеними з виявлених гельмінтозів були інвазії, зумовлені паразитуванням шлунково-кишкових гельмінтів, ЕІ становила 2,88 \% (з 417844 досліджених - 12045 інвазовано). Їх частка серед всіх виявлених гельмінтозів сягала 84,21\% (рис. 2).

Водночас, показники екстенсивності інвазії за гельмінтозів органів дихання становили 1,32\% (3 171456 досліджених - 2258 інвазовано), що склало 15,7 \% серед загальної кількості гельмінтозів. 


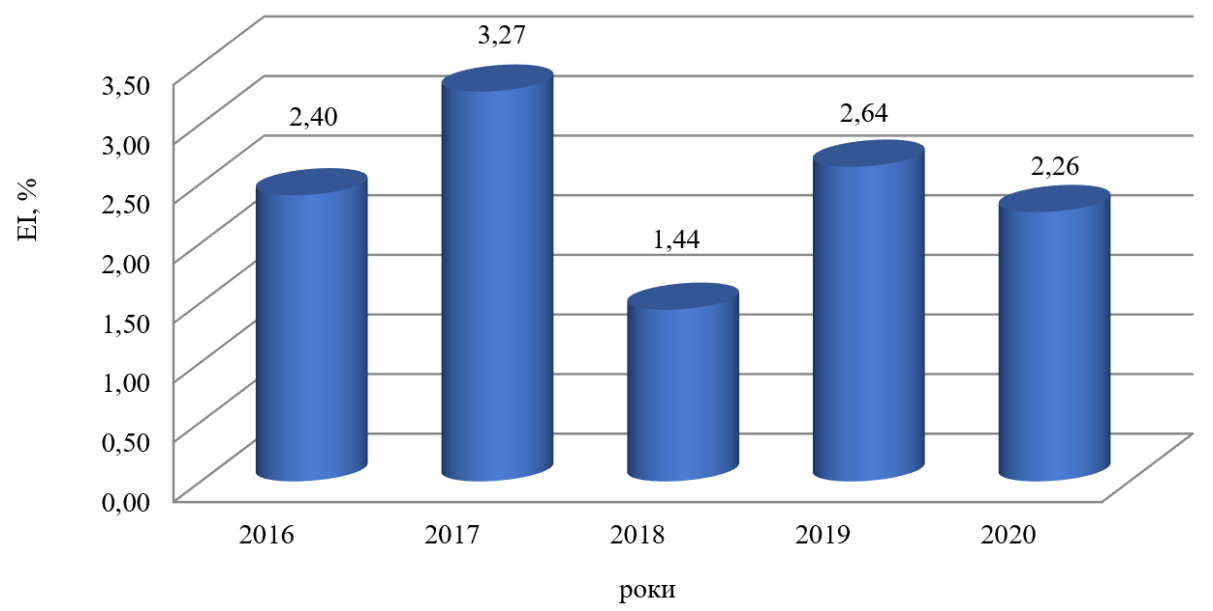

Рис. 1. Екстенсивність інвазії за гельмінтозів овець на території України (2016-2020рр.)

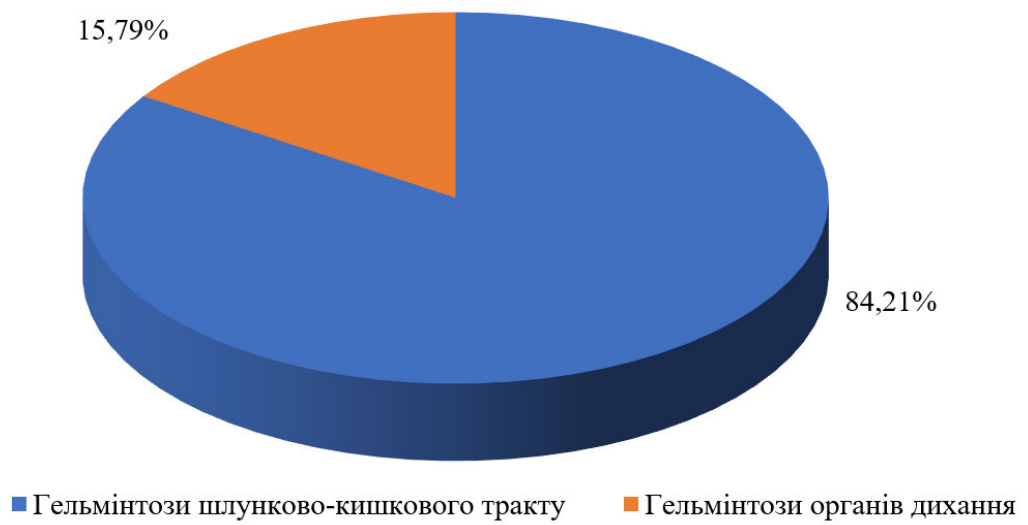

Рис. 2. Відсоткове співвідношення гельмінтозів органів травлення та гельмінтозів органів дихання на території України (2016-2020 pp.)

Виявлено, що серед гельмінтозів шлунковокишкового тракту овець переважали нематодози, де ЕI становила 6,27 \% (з 121162 досліджених - 7597 інвазовано). Рідше виявляли трематодози, ЕІ становила 1,65 \% (з 255971 досліджених - 4222 інвазовано). Серед трематодозів найбільш розповсюдженими були дикроцеліоз, ЕІ становила 1,79 \% (з 35994 досліджених - 645 інвазовано), фасціольоз, де ЕІ становила 1,66 \% (з 211196 досліджених - 3506 інвазовано) та парамфісто- матоз, де ЕІ становила 0,25 \% (з 24932 досліджених 61 інвазовано). Серед цестодозів виявляли: цистицерко3, де ЕІ становила $0,87 \%$ (з 115 досліджених - 1 інвазована) та монієзіоз, де ЕІ становила $0,65 \%$ (3 34706 досліджених - 225 інвазовано). Аналізуючи відсоткове співвідношення виявлених гельмінтозів можна зазначити, що частка нематодозів серед гельмінтозів травного каналу овець становила $63,07 \%$, трематодозів $-35,05 \%$, цестодозів - 1,88 \% (рис. 3 ).

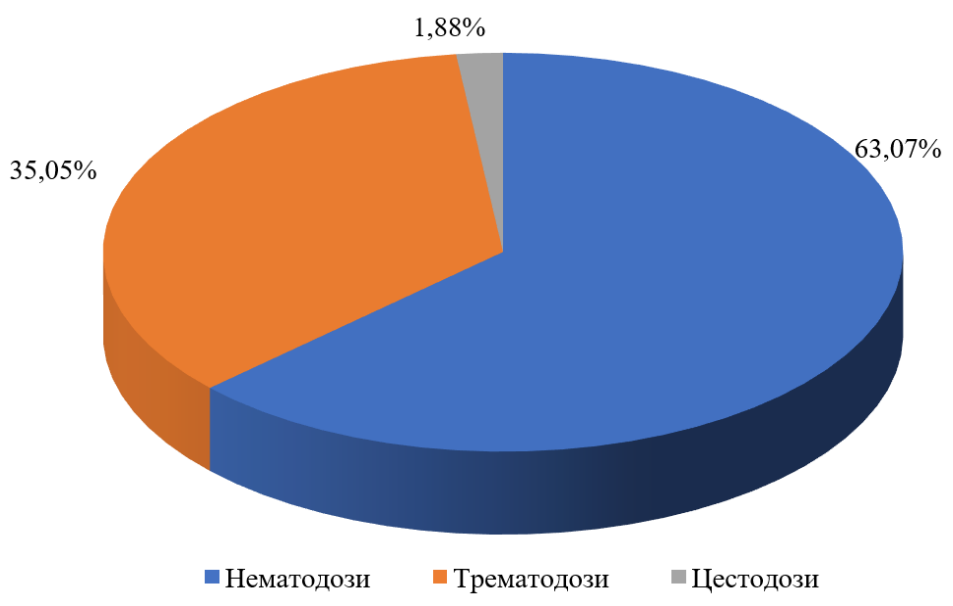

Рис. 3. Відсоткове співвідношення нематодозів, трематодозів та цестодозів, збудники яких паразитують в шлунково-кишковому тракті овець на території України (2016-2020рр.) 
При дослідженні захворюваності овець на нематодози шлунково-кишкового тракту виявили, що найбільш розповсюдженими були стронгілідози, зокрема буностомоз, нематодироз, гемонхоз, де ЕІ становила $10,98 \%$ (з 45109 досліджених - 4953 інвазовано) та стронгілоїдоз, де ЕІ становила 4,48 \% (з 57493 досліджених - 2577інвазовано). Меншу частку серед нематодозів шлунково-кишкового тракту овець становили езофагостомоз, де ЕІ склала 0,74 \% (з 13226 досліджених - 56 інвазовано) та трихуроз, де ЕІ склала 0,14 \% (з 5334 досліджених - 11 інвазовано). Показ- ники екстенсивності інвазії становили: за стронгілідозів (буностомоз, нематодіроз, гемонхоз) - 10,98 \%, за строгілоїдлзу - 4,48 \%, за езофагостомозу - 0,42 \%, за трихурозу - 0,21\% (рис. 4).

Отже, стронгілоїдоз овець є одним з найбільш поширених нематодозів шлунково-кишкового тракту овець за останні 5 років на території України.

У розрізі років показники ураження овець збудником стронгілоїдозу мали значні коливання із зростанням екстенсивності строгілоїдозної інвазї впродовж 2019-2020 років (рис. 5).

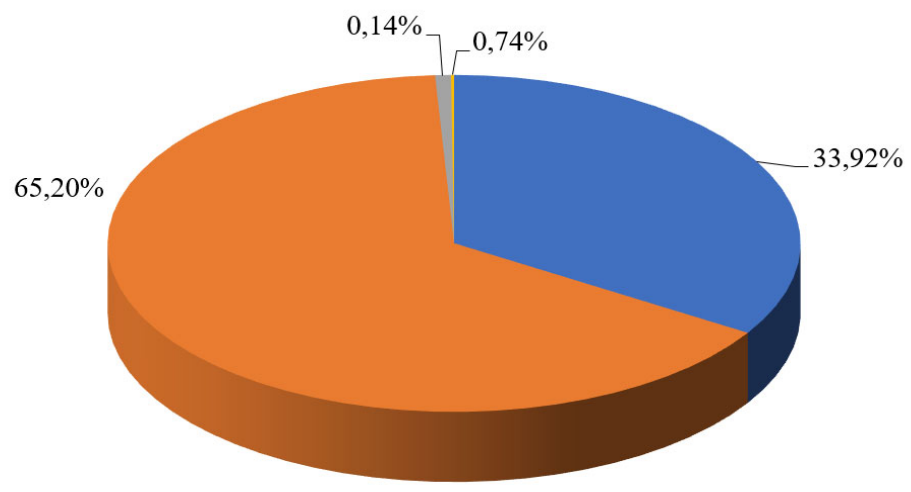

घ Стронгілоїдоз $\square$ Стронгілідози (буностомоз, гемонхоз, нематодіроз $\square$ Езофагостомоз $₫$ Трихуроз

Рис. 4. Відсоткове співвідношення нематодозів овець, що зареєстровано на території України (2016-2020рр.)

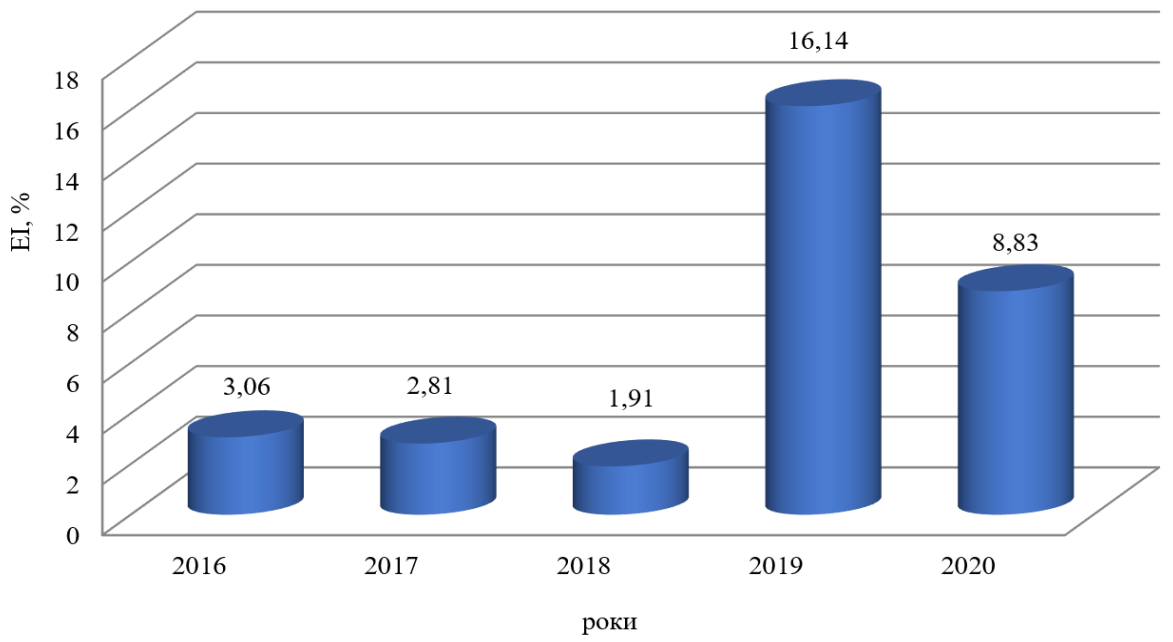

Рис. 5. Показники екстенсивності строгілоїдозної інвазії овець на території України (2016-2020рp.)

Зокрема, у 2016 р. ЕІ становила 3,06 \% (з 14167 досліджених - 434 інвазовано), у 2017 р. - 2,81 \% (з 15272 досліджених - 430 інвазовано), 2018 р. - 2,45\% (з 17080 досліджених - 418 інвазовано). В той же час впродовж 2019-2020 рр. спостерігали значне зростання рівня інвазованості овець збудником стронгілоїдозу. Так, екстенсивність стронгілоїдозної інвазії овець у 2019 р. досягла рівня 16,14 \% (3 4454 досліджених 719 інвазовано), у 2020 р. - 8,83 \% (з 6520 досліджених - 576 інвазовано).

Отже, отримані нами дані свідчать про значне поширення нематодозів шлунково-кишкового каналу, зокрема стронгілоїдозу овець на території України, про що свідчать статистичні дані звітної документації Державного науково-дослідного інституту з лабора- торної діагностики та ветеринарно-санітарної експертизи (м. Київ) впродовж 2016-2020 рр. 3'ясовано, що частка гельмінтозів травного каналу овець серед усіх виявлених гельмінтозів сягала 84,21 \%, частка нематодозів - 63,07\%. Зокрема, з нематодозів травного каналу найбільшого поширення набули стронгілідози $(62,50 \%)$ та стронгілоїдоз (33,92\%), який за останні роки мав зростання показників екстенсивності інвазії. Отримані нами дані підтверджуються результатами інший вчених, що свідчать про значне поширення стронгілоїдозу в більшості країн світу, зокрема в Японії (Ura et al., 1992; 1993; Nakanishi et al., 1993; Nakamura et al., 1994), Білорусі (Samsonovich, 2012), Ефіопії (Asmare et al., 2016), Англії, Шотландії, Уельсу та Північної Ірландії (McMahon et al., 2012). 
Отримані нами дані свідчать про актуальність проблеми щодо нематодозів, зокрема стронгілоїдозу овець у господарствах України і зумовлюють проведення більш грунтовних досліджень відносно епізоотологічних, біологічних особливостей збудника стронгілоїдозу та впровадження ефективних лікувальнопрофілактичних заходів.

\section{Висновки}

За результатами аналізу статистичних даних звітної документації Державного науково-дослідного інституту з лабораторної діагностики та ветеринарносанітарної експертизи (2016-2020рр.) встановлено, що стронгілоїдоз овець $є$ значно поширеною інвазією на території України. Частка стронгілоїдозу серед інших виявлених нематодозів травного тракту становила 33,92 \%. Показники екстенсивності інвазії овець збудником стронгілоїдозу за досліджений період на території України коливалися в межах від 1,91\% (2018 р.) до 16,14 \% (2019 р.).

\section{References}

Asmare, K., Sheferaw, D., Aragaw, K., Abera, M., Sibhat, B., Haile, A., Kiara, H., Szonyi, B., Skjerve, E., \& Wieland, B. (2016). Gastrointestinal nematode infection in small ruminants in Ethiopia: A systematic review and meta-analysis. Acta Tropica, 160, 68-77. doi: 10.1016/j.actatropica.2016.04.016.

Bhat, S. A., Rahman Mir, M. U., Qadir, S., Allaie, I. M., \& Khan, H. I. (2012). Husein I.Prevalence of gastrointestinal parasitic infections in Sheep of Kashmir valley of India. Veterinary World, 5(11), 667-671.

Bratushkina, E. L. (2003). Strongiloidozovec i mery bor'by $\mathrm{s}$ nim. Avtoreferat dysertatsii kandydata biologichnyh nauk. Minsk (in Russian).

Chemodankina, N. A. (2007). Strongiloidoz ovec v Saratovskoj oblasti (rasprostranenie, merybor'by). Avtoreferat dysertatsii kandydata veterinarnyh nauk. Saratov (in Russian).

Dixit, A. K., Das, G., \& Baghel, R. P. S. (2017). Gastrointestinal helminthosis: prevalence and associated determinants in goats of Jabalpur, India. Journal of Parasitic Diseases, 41(2), 414-416. doi: 10.1007/s12639-016-0818-x.

Kobayashi, I., Kajisa M., Farid, A. S., Yamanaka, A., \& Horii, Y. (2009). Paralytic ileus and subsequent death caused by enteric parasite, Strongyloides papillosus, in Mongolian gerbils. Veterinary Parasitology, 162(1-2), 100-105. doi: 10.1016/j.vetpar.2009.02.017.

McMahon, C., Gordon, A. W., Edgar, H. W., Hanna, R. E., Brennan, G. P., \& Fairweather, I. (2012). The effects of climate change on ovine parasitic gastroenteritis determined using veterinary surveillance and meteorological data for Northern Ireland over the period 1999-2009. Veterinary Parasitology, 190(1-2), 167-77. doi: 10.1016/j.vetpar.2012.06.016.

Nakamura, Y., Tsuji, N., Taira, N., \& Hirose, H. (1994). Parasitic females of Strongyloides papillosus as a pathogenetic stage for sudden cardiac death in infected lambs. Journal of Veterinary Medical Science, 56(4), 723-727. doi: 10.1292/jvms.56.723.

Nakanishi, N., Nakamura, Y., Ura, S., Tsuji, N., Taira, N., Tanimura, N., \& Kubo, M. (1993). Sudden death of calves by experimental infection with Strongyloides papillosus. III. Hematological, biochemical and histological examinations. Veterinary Parasitology, 47(12), 67-76. doi: 10.1016/0304-4017(93)90176-n.

Nwosu, C. O., Madu, P. P., \& Richards, W. S. (2007). Prevalence and seasonal changes in the population of gastrointestinal nematodes of small ruminants in the semi-arid zone of north-eastern Nigeria. Veterinary Parasitology, 144(1-2), 118-124. doi: 10.1016/j.vetpar.2006.09.004.

Samsonovich, V. A., Bratushkina, E. L., Patafeev, V. A., \& Makovskij, E. G. (2012). Rekomendacii po bor'be so trongiloidozami sel'skohozjajstvennyh zhivotnyh. VGAVM, Vitebsk (in Russian).

Shelest, L. S. (2005). Metodologichni aspekty eksperymental'noi' ekonomiky galuzi vivcharstva: monografija. Askanija-Nova (in Ukrainian).

Sultan, K., Elmonir, W., \& Hegazy, Y. (2016). Gastrointestinal parasites of sheep in Kafrelsheikh governorate, Egypt: Prevalence, control and public health implications. Beni-Suef University Journal of Basic and Applied Sciences, 5(1), 79-84. doi: 10.1016/i.bjbas.2015.12.001.

Taira, N., Nakamura, Y., Tsuji, N., Kubo, M., \& Ura, S. (1992). Sudden death of calves by experimental infection with Strongyloides papillosus. I. Parasitological observations. Veterinary Parasitology, 42(3-4), 247-56. doi: 10.1016/0304-4017(92)90066-i.

Taira, N., \& Ura, S. (1991). Sudden death in calves infected with Strongyloides papillosus. Veterinary Parasitology, 39(3-4), 313-319. doi: 10.1016/03044017(91)90048-z.

Tsuji, N., Itabisashi, T., Nakamura, Y., Taira, N., Kubo, M., Ura, S., \& Genno, A. (1992). Sudden cardiac death in calves with experimental heavy infection of Strongyloides papillosus. Journal of Veterinary Medical Science, 54(6), 1137-43. doi: 10.1292/jvms.54.1137.

Ura, S., Nakamura, Y., Tsuji, N., \& Taira, N. (1992). Sudden death of calves by experimental infection with Strongyloides papillosus. II. Clinical observations and analysis of critical moments of the disease recorded on videotape. Veterinary Parasitology, 44 (1-2), 107-110.

Ura, S., Taira, N., Nakamura, Y., Tsuji, N., \& Hirose, H. (1993) Sudden death of calves by experimental infection with Strongyloides papillosus. IV. Electrocardiographic and pneumographic observations at critical moments of the disease. Veterinary Parasitology, 47(34), 343-347. doi: 10.1016/0304-4017(93)90035-1.

Vdovychenko, Yu. V., \& Zharuk, P. H. (2013). Stan ta perspektyvy rozvytku haluzi vivcharstva Ukrainy. Visnyk Dnipropetrovskoho Derzhavnoho Universytetu, 1(13),135-138 (in Ukrainian).

Wymann, M. N., Bonfoh, B., Traore K., Tembely, S., \& Zinsstag, J. (2007). Species diversity and acquisition of gastrointestinal parasites in calves aged 0-13 months in periurban livestock production in Mali. Veterinary Parasitology, 143(1), 67-73. doi: 10.1016/j.vetpar.2006.07.025. 